\title{
Association between Serum Vitamin D and Diabetic Retinopathy in Portuguese Patients with Type 1 Diabetes
}

\author{
Associação entre a Vitamina D Sérica e a Retinopatia \\ Diabética numa População Portuguesa com Diabetes Tipo 1
}

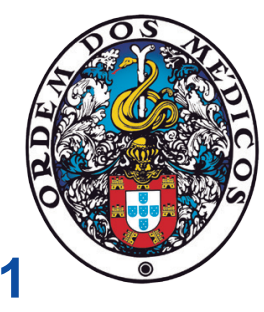

\author{
Miguel LOPES ${ }^{1}$, Rita LAIGINHAS ${ }^{1,2}$, Carolina MADEIRA ${ }^{3}$, João Sérgio NEVES ${ }^{4,5}$, Margarida BARBOSA ${ }^{1,6,7}$, \\ Vitor ROSAS ${ }^{3}$, Davide CARVALHO ${ }^{1,4}$, Fernando FALCÃO-REIS ${ }^{3,5}$, Manuel FALCÃO $\triangle^{3,5}$ \\ Acta Med Port 2020 Jul-Aug;33(7-8):459-465 - https://doi.org/10.20344/amp.12890
}

\section{ABSTRACT}

Introduction: Recently, vitamin D has gained importance as a diabetes risk modifier. Our aim was to assess the association between serum vitamin $D$ levels and the prevalence of diabetic retinopathy in patients with type 1 diabetes.

Material and Methods: Retrospective review of a population of patients with type 1 diabetes followed in a Portuguese tertiary center. Patients were included if they had an ophthalmological evaluation and a serum 25-hydroxyvitamin D level determination within the same year. Logistic regression analysis was used to adjust for possible confounders.

Results: We included 182 patients $(47 \%$ male), and $57 \%(n=103)$ had signs of diabetic retinopathy. We found a significant association between lower circulating levels of 25-hydroxyvitamin D levels and a greater prevalence of diabetic retinopathy after adjusting for confounders (duration of diabetes, estimated glomerular filtration rate, age, sex, metabolic control, season, dyslipidemia and hypertension) $(\mathrm{OR}=0.94 ; 95 \% \mathrm{Cl} 0.90-0.99, p=0.023)$. Longer duration of diabetes and worse metabolic control also remained associated with diabetic retinopathy in the multivariate analysis $(\mathrm{OR}=1.20 ; 95 \% \mathrm{Cl} 1.13-1.27, p<0.001$ and $\mathrm{OR}=4.13 ; 95 \% \mathrm{Cl} 1.34$ - 12.7, $p=0.013$, respectively).

Conclusion: Lower levels of vitamin D were associated with an increased prevalence of diabetic retinopathy in patients with type 1 diabetes, after adjusting for possible confounders. Future controlled studies may elucidate the molecular routes for this association as well as the role of supplementation in the prevention of diabetes microvascular complications.

Keywords: Diabetes Mellitus, Type 1; Diabetic Retinopathy; Portugal; Vitamin D; Vitamin D Deficiency

\section{RESUMO}

Introdução: A vitamina D tem vindo a ganhar importância como um modificador do risco de diabetes. O objetivo deste estudo foi avaliar a associação entre os níveis séricos de vitamina $D$ e a prevalência de retinopatia diabética em pacientes com diabetes tipo 1. Material e Métodos: Estudo retrospetivo de uma população de doentes com diabetes tipo 1, seguidos num centro hospitalar terciário português. Os pacientes foram incluídos se tivessem uma avaliação oftalmológica e um doseamento dos níveis de 25-hidroxivitamina D no mesmo ano. Os ajustes para eventuais variáveis confundidoras foi realizado recorrendo a uma análise de regressão logística.

Resultados: Foram incluídos 182 doentes (47\% sexo masculino), dos quais $57 \%(n=103)$ demonstravam sinais de retinopatia diabética. Foi encontrada uma associação significativa entre níveis inferiores de 25-hidroxivitamina D circulante sérica e uma maior prevalência de retinopatia diabética, depois do ajuste para os confundidores incluídos (duração da diabetes, taxa de filtração glomerular estimada, idade, sexo, controlo metabólico, estação do ano, dislipidemia e hipertensão) (OR =0,94; 95\% IC 0,90 - 0,99, $p=0,023$ ). Uma maior duração da diabetes, assim como um pior controlo metabólico, mantiveram também uma associação significativa com uma maior prevalência de retinopatia diabética na análise multivariada $(\mathrm{OR}=1,20 ; 95 \%$ IC 1,13 - 1,27, $p<0,001 ; \mathrm{OR}=4,13$; 95\% IC $1,34-12,7, p=0,013$, respetivamente).

Conclusão: Níveis inferiores de vitamina $D$ séricos demonstraram-se associados a uma prevalência superior de retinopatia diabética em pacientes com diabetes tipo 1, após o ajuste para eventuais variáveis confundidoras. Futuramente, estudos experimentais poderão estabelecer as vias moleculares implicadas nesta associação, assim como um papel concreto da suplementação na prevenção das complicações microvasculares da diabetes.

Palavras-chave: Deficiência de Vitamina D; Diabetes Mellitus Tipo 1; Portugal; Retinopatia Diabética; Vitamina D

\section{INTRODUCTION}

Diabetic retinopathy (DR) is the most sight-threatening complication of type 1 diabetes (T1D), and it remains one of the most worrisome emerging causes of blindness, particularly among working-age individuals. ${ }^{1,2}$ It is known that metabolic control and duration of diabetes are independent risk factors for DR. ${ }^{3}$ However, other pathophysiological mechanisms involved in this condition are not fully clarified.
Vitamin $D$ has been known to regulate bone and mineral homeostasis. ${ }^{4}$ However, aside from this role, several recent studies have linked vitamin $D$ to the pathogenesis of diabetes ${ }^{5}$ and there is growing evidence that vitamin $\mathrm{D}$ can interfere with the mechanisms involved in diabetes and its complications. ${ }^{6}$ In in vitro studies, vitamin D showed a beneficial action in pancreatic islets, ${ }^{7}$ demonstrating a

\footnotetext{
1. Faculty of Medicine. Porto University. Porto. Portugal.

2. Department of Ophthalmology. Centro Hospitalar de Entre o Douro e Vouga. Santa Maria da Feira. Portugal.

3. Department of Ophthalmology. Centro Hospitalar de São João. Porto. Portugal.

4. Department of Endocrinology, Diabetes and Metabolism. Centro Hospitalar de São João. Porto. Portugal.

5. Department of Surgery and Physiology. Faculty of Medicine. University of Porto. Porto. Portugal.

6. Department of Anesthesiology. Centro Hospitalar de São João. Porto. Portugal.

7. I3S Instituto de Investigação e Inovação em Saúde. University of Porto. Porto. Portugal.

$\triangle$ Autor correspondente: Manuel Falcão. falcao@med.up.pt

Recebido: 30 de novembro de 2019 - Aceite: 06 de fevereiro de 2020 | Copyright $\odot$ Ordem dos Médicos 2020
} 
protective effect on cytokine-suppressed insulin release by $1,25(\mathrm{OH}) 2 \mathrm{D} 3$, both in human and mouse models. ${ }^{8}$ Some studies have pointed out vitamin $\mathrm{D}$ deficiency as a risk factor for T1D as the genetic background of vitamin D deficiency has demonstrated strong associations with T1D. ${ }^{9}$

Vitamin $D$ has been shown to play an important part in the regulation of angiogenesis, being an inhibitor of the HIF-1 1 /VEGF pathway in cancer cells. ${ }^{10}$ Other more recent studies highlighted the molecular basis of a protective effect of vitamin $D$ in the specific context of DR, as it decreased diabetes-induced reactive oxygen species (ROS) and inhibited the ROS/TXNIP/NLRP3 inflammasome pathway, protecting against retinal vascular damage and cell apoptosis. ${ }^{11}$ One study has highlighted both the anti-inflammatory and anti-angiogenic properties of vitamin $D$ in the retinal tissue in vivo, indicating that it prevents the development and progression of DR by decreasing inflammation and neovascularization. ${ }^{12}$ Genetics have also been emphasized in this field, showing that a polymorphism, which increases the transcription of the vitamin $\mathrm{D}$ receptor and thus its biological activity, results in less severe DR in T1D patients. ${ }^{13}$

There is increasing evidence suggesting an association between vitamin $D$ deficiency and diabetic retinopathy in type 2 diabetes patients. ${ }^{14-17}$ However, literature remains scarce regarding this association in T1D patients, and some contradictory findings have been reported. ${ }^{18-21}$

The present study aims to evaluate the association between serum vitamin $D$ levels and the prevalence of $D R$ in T1D patients.

\section{MATERIAL AND METHODS}

This was an observational retrospective study of a population of T1D patients followed in a tertiary eye care center (Centro Hospitalar Universitário de S. João - CHUSJ, Porto, Portugal). All procedures were performed in accordance with the ethical standards of the Ethics Committee of Centro Hospitalar de São João/Faculty of Medicine of Porto University and with the 1964 Helsinki Declaration and its later amendments or comparable ethical standards, having the present study been approved by this institution without the need of written informed consent given the nature of the study.

\section{Sampling}

Our target population consisted of all patients diagnosed with T1D from the catchment area of CHUSJ (approximately 300000 people), aged over 18 years, and alive at the time of the study (2018).

According to the last available census and epidemiological records from 2011, the hospital referral region of this tertiary center has a population of around 340000,200000 of which are aged above 18 years. ${ }^{22}$ A Portuguese study has estimated the prevalence of T1DM in Northern Portugal to be 1.66 cases per $1000 .^{23}$ Assuming these estimations, a population of about 332 T1DM patients is expected in our referral region.

By merging medical registries, we found 469 subjects diagnosed with T1D between 1950 and 2017 and we reviewed their medical records. From those, we excluded the cases in which the diagnosis of T1D was doubtful by analyzing medical records (uncertainty about type 1 or type 2 diabetes), as well as those without an ophthalmological observation and a serum vitamin $\mathrm{D}$ level determination within the same year.

After applying the exclusion criteria, a total of 182 patients were included. The sample size met our initial estimates, and we were able to consider the sample as an adequate representation of our target population. The patient selection process is further explained in Fig. 1.

\section{Clinical and laboratorial data}

We reviewed clinical and laboratory data from the selected sample. Patients were excluded if they had incomplete medical records, namely regarding date of T1D diagnosis, complete ophthalmological evaluation mentioning diabetic retinopathy stage, and serum 25-hydroxyvitamin D level determination within the same year of the last ophthalmological evaluation.

DR status was classified as present/absent based on fundoscopy findings in medical records from the last ophthalmological evaluation. We considered absent DR if there was no evidence in medical records of any DR manifestation (microaneurysms, cotton wool spots, intra-retinal hemorrhages, or macular edema).

We also analyzed subjects based on the presence and type of DR according to the following stratification ${ }^{24}$ : mild non-proliferative DR; moderate to severe non-proliferative DR and proliferative retinopathy (PDR). People with panretinal photocoagulation were also included in the PDR group. If there was asymmetric retinopathy, the eye in worse condition was used for classification.

Total 25-hydroxyvitamin D levels $(\mathrm{ng} / \mathrm{mL})$ were obtained from the patient's clinical records. The month when the measurement was assessed was also recorded to verify if there was any circannual pattern of variation. Vitamin $D$ deficiency was defined at a 25-hydroxyvitamin $\mathrm{D}$ level $\leq$ $20 \mathrm{ng} / \mathrm{mL}$, insufficiency at $21-29 \mathrm{ng} / \mathrm{mL}$ and sufficiency at $30-100 \mathrm{ng} / \mathrm{mL}$, according to international clinical practice guidelines. ${ }^{25}$

Data regarding sex, age, disease duration and age at T1D diagnosis were also collected. We extracted all available glycated hemoglobin (HbA1c) levels in the medical records for each patient. We used the final averaged value as an estimate of the patient's metabolic control.

Further data extracted for analysis included history of hypertension, dyslipidemia, peripheral neuropathy, and nephropathy (classified as present/absent).

Data regarding laboratory parameters were also collected. For the following variables, the last two available measurements at the follow-up for each patient were averaged and inputed for analysis: total cholesterol, high and lowdensity lipoprotein, triglycerides, serum creatinine, uric acid and 24-hour albuminuria. Glomerular filtration rate was estimated from serum creatinine using the CKD-EPI (Chronic 


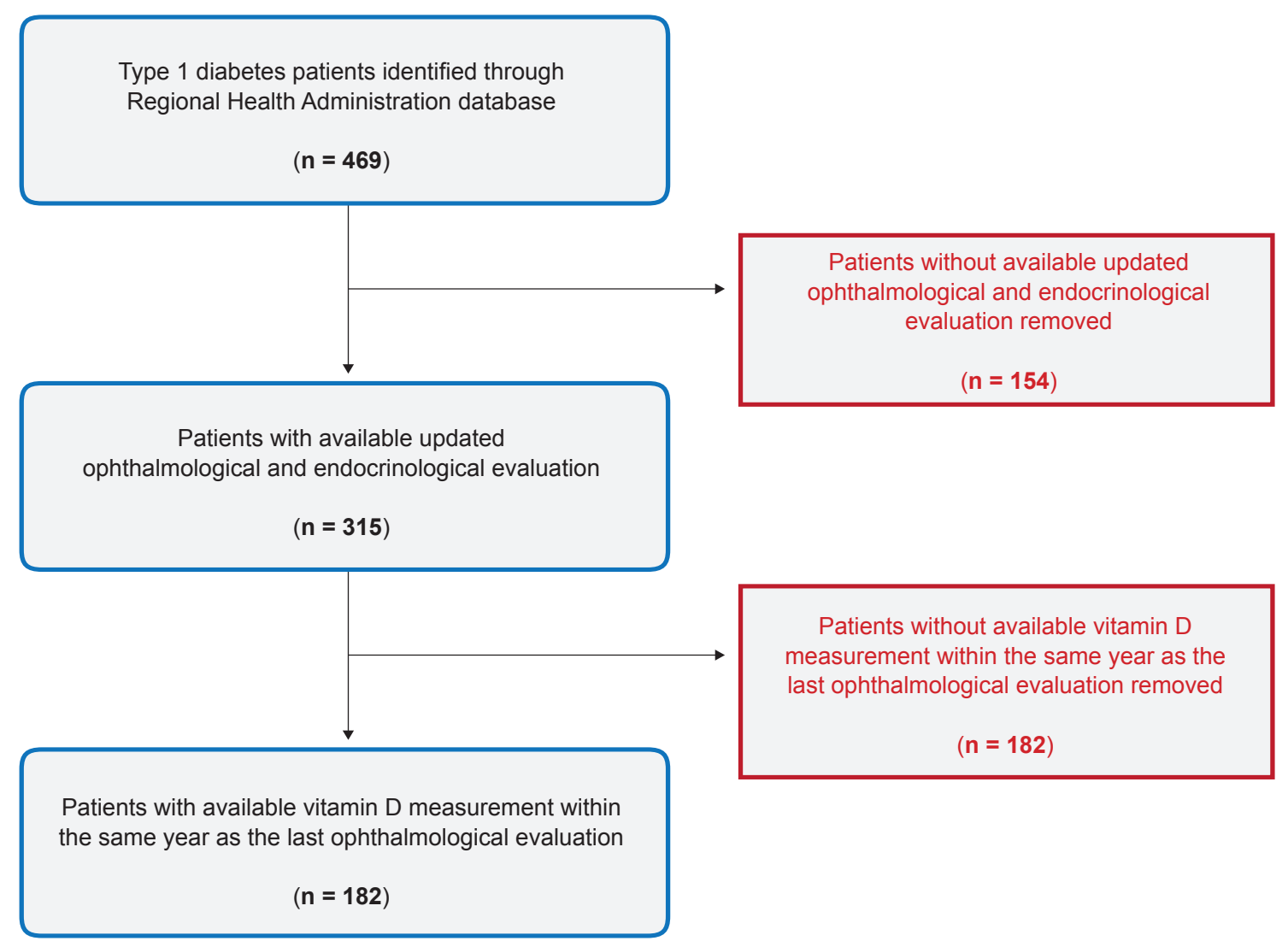

Figure 1 - Patient selection flow chart

Kidney Disease Epidemiology Collaboration) equation. ${ }^{26}$

\section{Potential confounders}

In this analysis, we included potential confounders in the relationship between 25-hydroxyvitamin $\mathrm{D}$ levels and DR. We opted to evaluate the potential effect of age and sex in our model.

Duration of the disease (years) and metabolic control (dichotomized as good/bad) were included, as they are known to the be the main determinants for DR in patients with T1D. ${ }^{3}$ Good metabolic control was defined as an average $\mathrm{HbA} 1 \mathrm{c}<7 \%$, according to the latest recommendations of the American Diabetes Association. ${ }^{27}$

History of hypertension and dyslipidemia were also included as potential confounders as they have been associated with vitamin $\mathrm{D}$ status. ${ }^{28,29}$ It is known that vitamin $\mathrm{D}$ deficiency $(<20 \mathrm{ng} / \mathrm{mL})$ and insufficiency $(20-29 \mathrm{ng} / \mathrm{mL})$ are common among patients with chronic kidney disease, ${ }^{30}$ and we included an adjustment for glomerular filtration rate to account for this potential confounder effect.

Vitamin $D$ is a secosteroid that is generated in the skin under the influence of sunlight. ${ }^{31}$ As human sun exposure is related to the seasonal position of the sun, vitamin $D$ is generated at different rates according to the season. To encompass this potential variation, we included an adjustment for the season by dividing the year according to common seasonal sun positions in Portugal.

All things considered, we performed a multiple logistic regression model for predicting the presence of $D R$, and included 25-hydroxyvitamin D levels as well as the adjustments for the following variables: duration of T1D, age, sex, estimated glomerular filtration rate, hypertension, dyslipidemia, metabolic control and seasonal variation.

\section{Statistical analysis}

Descriptive statistics have been used to document comparability of baseline characteristics. Normal distribution was checked by histogram visual inspection. Categorical variables are presented as frequencies and percentages, and continuous variables are represented as mean \pm standard deviation or median (interquartile range), according to their normal distribution status. Comparisons of vitamin D levels in patients with and without DR and among different types of DR were performed using the Mann-Whitney and Kruskal-Wallis tests.

We analyzed the association between vitamin $D$ levels and any DR, including potential adjustments, using multiple logistic regression. We also analyzed this relationship in the different DR stages. A two-sided value of $p<0.05$ was considered statistically significant. The statistical analysis was performed using IBM SPSS Statistics 25 software.

\section{RESULTS}

From our initial population of 469 patients, a total of 182 patients presented a serum vitamin $D$ level determination within the same year as an ophthalmological evaluation. 
Table 1 - Clinical and biochemical characteristics of type 1 diabetes patients by diabetic retinopathy status

\begin{tabular}{lccc} 
& $\begin{array}{c}\text { No Retinopathy } \\
(\mathrm{n}=79)\end{array}$ & $\begin{array}{c}\text { Retinopathy } \\
(\mathrm{n}=103)\end{array}$ & $p$ value \\
\hline Male, $\mathrm{n}(\%)$ & $35(44)$ & $51(50)$ & 0.55 \\
Age, mean $\pm \mathrm{SD}$ (years) & $37.1 \pm 13.2$ & $46.7 \pm 13.9$ & $<0.001^{*}$ \\
T1D duration, mean $\pm \mathrm{SD}($ years) & $11.6 \pm 8.2$ & $27.0 \pm 10.9$ & $<0.001^{*}$ \\
HbA1c, mean $\pm \mathrm{SD}(\% ; \mathrm{mmoL} / \mathrm{moL})$ & $8.0 \pm 1.7(64 \pm 19)$ & $8.5 \pm 1.7(69 \pm 19)$ & $0.04^{*}$ \\
BMI, mean $\pm \mathrm{SD}\left(\mathrm{kg} / \mathrm{m}^{2}\right)$ & $24.5 \pm 5.0$ & $24.5 \pm 5.5$ & 0.70 \\
25(OH)D, mean $\pm \mathrm{SD}(\mathrm{ng} / \mathrm{mL})$ & $22.7 \pm 11.1$ & $20.3 \pm 10.7$ & 0.30 \\
eGFR, mean $\pm \mathrm{SD}\left(\mathrm{mL} / \mathrm{min} / 1.73 \mathrm{~m}^{2}\right)$ & $114.6 \pm 20.3$ & $95.7 \pm 31.4$ & $<0.001^{*}$ \\
Albuminuria, median $(\mathrm{IQR})(\mathrm{mg} / 24 \mathrm{~h})$ & $6(7.6)$ & $11.5(45.8)$ & $<0.001^{*}$ \\
Hypertension, $\mathrm{n}(\%)$ & $16(21)$ & $53(51)$ & $<0.001^{*}$ \\
Dyslipidemia, $\mathrm{n}(\%)$ & $24(32)$ & $67(66)$ & $<0.001^{*}$ \\
\hline
\end{tabular}

Data are presented as mean \pm standard deviation (SD), median (interquartile range) (IQR) or as $n(\%)$. The values represent means at the last evaluation.

T1D: type 1 diabetes mellitus; HbA1c: glycated hemoglobin; BMI: body mass index; 25(OH)D: 25-hydroxyvitamin D; eGFR: estimated glomerular filtration rate

*: Values were significantly different between groups in the unadjusted analysis, assuming a two-sided value of $p<0.05$ as statistically significant.

Table 2 - Clinical and biochemical characteristics of the patients included in the initial sample $(n=315)$

\begin{tabular}{|c|c|c|c|}
\hline & $\begin{array}{l}\text { Patients included } \\
\text { in the analysis } \\
(n=182)\end{array}$ & $\begin{array}{l}\text { Patients excluded } \\
\text { from the analysis } \\
\qquad(n=133)\end{array}$ & $p$ value \\
\hline Male, $n(\%)$ & $86(47)$ & $75(56)$ & $<0.001^{*}$ \\
\hline Age at diagnosis, mean $\pm \mathrm{SD}$ (years) & $20.1 \pm 12.4$ & $23.1 \pm 13.3$ & $0.038^{*}$ \\
\hline T1D duration, mean \pm SD (years) & $20.3 \pm 12.4$ & $18.8 \pm 12.4$ & 0.207 \\
\hline HbA1c, mean \pm SD $(\% ; \mathrm{mmoL} / \mathrm{moL})$ & $8.3 \pm 1.7$ & $8.4 \pm 1.6$ & 0.651 \\
\hline DR, n (\%) & $103(57)$ & $67(50)$ & 0.274 \\
\hline BMI, mean \pm SD $\left(\mathrm{kg} / \mathrm{m}^{2}\right)$ & $24.5 \pm 5.3$ & $25.2 \pm 5.6$ & 0.139 \\
\hline Hypertension, n (\%) & $69(38)$ & $50(38)$ & 0.970 \\
\hline Dyslipidemia, n (\%) & $91(50)$ & $55(41)$ & 0.188 \\
\hline
\end{tabular}

Data are presented as mean \pm standard deviation (SD) or as $n(\%)$. The values represent means at the last evaluation.

T1D: type 1 diabetes mellitus; HbA1c: glycated hemoglobin; BMI: body mass index; DR: diabetic retinopathy.

*: Values were significantly different between groups assuming a two-sided value of $p<0.05$ as statistically significant.

Of this sample, $86(47 \%)$ were male. The mean age at the evaluation was $43 \pm 14$ years and the mean disease duration was $20 \pm 12$ years.

In the evaluation, 103 patients $(57 \%)$ had fundus manifestation of DR, and the mean 25-hydroxyvitamin $D$ level was $21.3 \pm 10.9 \mathrm{ng} / \mathrm{mL}$. Table 1 details the clinical and biochemical characteristics of our sample, according to DR status. Further details regarding the characteristics of the excluded patients can be found in Table 2.

According to the adopted criteria, 53\% ( $n=96)$ of patients had vitamin $\mathrm{D}$ deficiency (25-hydroxyvitamin $\mathrm{D}$ level $\leq$ $20 \mathrm{ng} / \mathrm{mL}), 26 \%(\mathrm{n}=48)$ had vitamin D insufficiency (21 - 29 $\mathrm{ng} / \mathrm{mL})$ and $21 \%(\mathrm{n}=38)$ had adequate levels $(30-100 \mathrm{ng} /$ $\mathrm{mL})$.

Seasonal variation of the 25-hydroxyvitamin D levels according to the month in which the samples were taken is demonstrated in Fig. 1. The levels followed the expected circannual pattern of variation according to the sun exposure in Portugal: the highest levels were recorded during the summer, as the lowest occurred during the winter.

We stratified vitamin $D$ levels in different duration of diabetes intervals, and we found that mean 25-hydroxyvitamin $\mathrm{D}$ levels were constantly higher in patients without DR. For patients with a duration of diabetes $<25$ years, the mean 25-hydroxyvitamin D serum level was $19.1 \mathrm{ng} / \mathrm{mL}$ if $\mathrm{DR}$ was present $(n=46)$ and $21.7 \mathrm{ng} / \mathrm{mL}$ if DR was absent $(n=71)$, $p=0.42$. For patients with a duration of diabetes $\geq 25$ years, mean 25-hydroxyvitamin D serum level was $21.3 \mathrm{ng} / \mathrm{mL}$ if DR was present $(n=57)$ and $31.6 \mathrm{ng} / \mathrm{mL}$ if $D R$ was absent $(\mathrm{n}=8)(p=0.02)$.

We also stratified vitamin $D$ levels by type of DR: no DR $(n=81)$, mild DR $(n=35)$, moderate to severe DR $(n=30)$ and PDR $(n=36)$. We did not find any statistically significant association between the mean vitamin $D$ levels and the severity of the DR (mean vitamin $D$ in patients without DR $=22.6 \pm 11.2 \mathrm{ng} / \mathrm{mL}$, with mild $\mathrm{DR}=21 \pm 9.5 \mathrm{ng} / \mathrm{mL}$; with moderate to severe $\mathrm{DR}=20.3 \pm 11.8 \mathrm{ng} / \mathrm{mL}$; with $\mathrm{PDR}=$ $19.8 \pm 10.8 \mathrm{ng} / \mathrm{mL} ; p=0.56)$. 
Table 3 - Multivariate regression analysis of retinopathy in type 1 diabetes patients

\begin{tabular}{lccc}
\hline Variable & OR & $95 \%$ CI & $p$ value \\
\hline 25-hydroxyvitamin D, ng/mL & 0.94 & $0.90-0.99$ & $0.023^{*}$ \\
Age, years & 1.03 & $0.98-1.08$ & 0.224 \\
Sex (male) & 2.00 & $0.80-4.94$ & 0.140 \\
T1D duration, years & 1.20 & $1.13-1.27$ & $<0.001^{*}$ \\
eGFR, mL/min/1.73m² & 0.99 & $0.97-1.02$ & 0.557 \\
Hypertension & 1.59 & $0.50-4.99$ & 0.431 \\
Dyslipidemia & 0.69 & $0.25-1.93$ & 0.484 \\
Season & 0.65 & $0.23-1.83$ & 0.417 \\
HbA1c $>$ 7\% & 4.13 & $1.34-12.7$ & $0.013^{*}$ \\
\hline
\end{tabular}

T1D: type 1 diabetes mellitus; HbA1c: glycated hemoglobin; eGFR: estimated glomerular filtration rate: OR: odds ratio. $95 \% \mathrm{Cl}$ : $95 \%$ confidence interval.

*: Values were significantly different between groups assuming a two-sided value of $p<0.05$ as statistically significant.

We performed a multiple logistic regression model for predicting the presence of DR, and included 25-hydroxyvitamin $D$ levels as well as the adjustments for the duration of T1D, age, sex, estimated glomerular filtration rate, hypertension, dyslipidemia, metabolic control and seasonal variation (Table 3). After the adjustments, duration of T1D, metabolic control and lower 25-hydroxyvitamin $D$ levels remained associated with a greater prevalence of diabetic retinopathy. The final model was able to explain $61 \%$ (Nagelkerke $R^{2}$ ) of the outcome.

\section{DISCUSSION}

In the present study, we found that lower serum 25-hydroxyvitamin $D$ levels were associated with an increased prevalence of DR in a sample of Portuguese T1D patients after adjusting for possible confounders. It is possible that higher serum levels of vitamin $D$ may have a protective effect on the development of DR.

Recently, vitamin $D$ has gained importance as a type 2 diabetes risk modifier. This was initially suggested by the observation of a seasonal variation in the glycemic control where it was perceived to be worse during the winter season. ${ }^{32}$ Additional evidence of a role played by vitamin $\mathrm{D}$ in type 2 diabetes comes from a large number of observational and cross-sectional studies that showed an inverse relationship between prevalence of type 2 diabetes and its complications and the vitamin $\mathrm{D}$ levels. Although there are several epidemiological studies reporting the association between vitamin $D$ and $D R$ in patients with diabetes ${ }^{14-21}$, to our knowledge, only four evaluated the association between DR and vitamin D in T1D. ${ }^{18-21}$ Kaur et a/18 performed a cross-sectional study of 517 T1D adolescents aged $8-20$ years and found lower vitamin D levels in DR cases. Shimo et a $/^{19}$ reached the same conclusions when analyzing 75 young T1D Japanese patients. However, the previous studies are limited in the fact that they only analyzed younger individuals, which means that most of them would not have had enough time to have developed retinal disease. Contrasting with these results, Joergensen et a ${ }^{20}$ reviewed 227 T1D patients and concluded that vitamin $D$ deficiency was a predictor of all-cause mortality but not development of microvascular complications in the eye and kidney. However, this study only analyzed cases with severe vitamin $D$ deficiency [defined as a plasma $25(\mathrm{OH}) \mathrm{D} 3$ value equal to or below the $10 \%$ percentile $-6.2 \mathrm{ng} / \mathrm{mL}$, and less severe deficits are underrepresented. In addition, the authors highlight, as a limitation, that the results could be due to the lack of power based on a low number of events, as the hazard ratio for both retinopathy and albuminuria was above 1 in patients with severe vitamin $D$ deficiency. Finally, a study from the EURODIAB Prospective Complications Study ${ }^{21}$ concluded that vitamin $D$ levels were not independently associated with non-proliferative or proliferative retinopathy. In this study, the adjustments did not include the duration of disease, the strongest predictor for DR development. As seen in our sample, it is possible that confounders can conceal eventual associations.

Although the role of vitamin $D$ in the pathophysiology of diabetes, is a subject of debate in the scientific community, there are several mechanisms that support a protective effect. Vitamin D can affect the key processes that are involved in diabetes: insulin resistance, insulin secretion and inflammation. ${ }^{28}$ Vitamin $\mathrm{D}$ can affect insulin resistance by stimulating the insulin receptor expression, as it enhances the transcriptional activation of the insulin receptor gene. This has been shown in an in-vitro study exposing human promonocytic cells to active vitamin $\mathrm{D}$, leading to an increased expression of mRNA encoding for insulin receptors and a 1.3 fold increase in glucose transport when compared to untreated cells..$^{33}$ The effect of vitamin D on insulin secretion and beta cell occurs through the regulation of extracellular calcium concentration and flux through the beta cell, as insulin secretion is a calcium dependent process. ${ }^{28}$ In addition, glucose and sulfonylurea-stimulated insulin secretion was shown to be lower in the islets of vitamin D-deficient rats, when compared to the islets of vitamin D-sufficient rats or vitamin $\mathrm{D}$ deficient rats with vitamin $\mathrm{D}$ replacement. ${ }^{34} \mathrm{Vi}-$ tamin $\mathrm{D}$ also interferes in the downregulation of NF-kB, a major transcription factor for TNF- $\alpha$ and other pro-inflammatory molecules. ${ }^{35}$ Moreover, vitamin $\mathrm{D}$ can have other important effects in inflammatory cytokines by interfering with a number of other genes or transcription factors involved in 
Table 4 - Prevalence of different DR status according to request of serum vitamin D measurement by the attending physician

\begin{tabular}{|c|c|c|c|}
\hline & $\begin{array}{c}\text { Patients with } \\
\text { serum vitamin } D \text { measurement } \\
(n=182)\end{array}$ & $\begin{array}{l}\text { Patients without } \\
\text { serum vitamin } D \text { measurement } \\
\qquad(n=133)\end{array}$ & $\begin{array}{c}\text { Fisher exact test } \\
\text { p value }\end{array}$ \\
\hline No DR & $44.5 \%$ & $46.9 \%$ & \multirow{4}{*}{0.572} \\
\hline Minimal NPDR & $19.2 \%$ & $18.8 \%$ & \\
\hline Moderate to severe NPDR & $16.5 \%$ & $17.3 \%$ & \\
\hline PDR & $19.8 \%$ & $14.3 \%$ & \\
\hline
\end{tabular}

DR: diabetic retinopathy; NPDR: non proliferative diabetic retinopathy; PDR: proliferative diabetic retinopathy

cytokine generation. ${ }^{36}$

Regarding DR, the literature remains scarce in detailing the mechanisms which can explain the protective properties of vitamin $D$. Research has indicated that vitamin $D$ prevents the development and progression of $\mathrm{DR}$ by inhibiting inflammation and neovascularization in retinal tissues. In an experimental study using rats with $\mathrm{DR},{ }^{12}$ the histopathological examination showed the appearance of edema and disordered arrangement of retinal tissues in a non-vitamin D supplemented group, but milder pathological changes in a supplemented group. Vitamin $\mathrm{D}$ has also been shown to reduce the level of diabetes-induced proinflammatory cytokines, playing a protective role against retinal vascular damage and cell apoptosis. ${ }^{11}$

However, despite having pointed out an association between lower serum vitamin $D$ levels and the presence of DR, our study failed to show an association with the severity of the disease. This could be due to the small sample size for this comparison and its necessary adjustments, or because vitamin $D$ does not play such an important part in the pathophysiology of the later stages of the disease.

An important aspect to point out is the overall low mean level of serum vitamin $D$ in our sample. The main perspective for this problem is the specific context of vitamin $D$ deficiency epidemiology in Portugal. A recent study carried out by the Dr. Ricardo Jorge National Institute of Health concluded that, in comparison to other European populations, the mean 25-hydroxyvitamin D levels observed in Portuguese populations were relatively lower. ${ }^{37}$ Another major epidemiological study carried out in 2017, the PROMETS study, which, among other things, evaluated the vitamin D levels of a nation-wide sample, showed that only $14.4 \%$ of the patients had vitamin D levels greater than $20 \mathrm{ng} / \mathrm{mL}^{38}$ Two other studies carried out in older patients yielded similar results, ${ }^{39,40}$ which suggests that the lower overall vitamin D levels we found may be related to a populational trend. From this data, we can conclude that there is still some controversy regarding the cut-offs established for the vitamin $D$ levels, and that definitions should consider the geographical patterns.

The major limitation of our study is its retrospective design. From the study, it is not possible to evaluate vitamin $D$ levels in the past and how eventual changes in its levels interfered with the development of DR. Also, the fact that we only analyzed a single hospital narrows the generalizability of the results. Another limitation of our study is that we were not able to determine quantitative sun exposure and dietary supplementation, as well as some systemic medication, which are important factors that can influence vitamin D levels. ${ }^{41}$ Vitamin $D$ measurements are not routinely performed in all patients and this could lead to a selection bias by the attending physician. However, we did not find significant differences between the sample with the vitamin $D$ measurements and the initial sample in terms of disease severity (Table 4).

Nevertheless, our study presents as a major strength the fact that it evaluates both adolescents and adults with T1D. This stands out from previous studies, as most of these only included young individuals and therefore, not many years of systemic disease. By including older patients, we present a wider and more comprehensive evaluation of this comparison throughout the whole age spectrum.

It is possible that vitamin $D$ is implicated in the pathophysiology of $\mathrm{DR}$, and further studies are needed so that we can establish the biological pathways for this phenomenon, as well as evaluate future roles for supplementation.

\section{CONCLUSION}

This study supports an association between lower vitamin D levels and a greater prevalence of DR in T1D patients. Unfortunately, despite improvements in glucose control, diabetic complications are still common, leading most researchers to look for other preventive measures.

\section{PROTECTION OF HUMAN SUBJECTS}

The authors declare that the procedures were followed according to the regulations established by the Clinical Research and Ethics Committee and to the Helsinki Declaration issued by World Medical Association.

\section{CONFIDENTIALITY OF DATA}

The authors declare having followed the protocols in use at their working center regarding patients' data publication.

\section{CONFLICTS OF INTEREST}

All authors declare no conflicts of interest.

\section{FINANCIAL SOURCES}

No funding was received for this research. 


\section{REFERENCES}

1. Prokofyeva E, Zrenner E. Epidemiology of major eye diseases leading to blindness in Europe: a literature review. Ophthalmic Res. 2012;47:17188.

2. Congdon N, Zheng $\mathrm{Y}, \mathrm{He} \mathrm{M}$. The worldwide epidemic of diabetic retinopathy. Indian J Ophthalmol. 2012;60:428.

3. Yau JW, Rogers SL, Kawasaki R, Lamoureux EL, Kowalski JW, Bek T, et al. Global prevalence and major risk factors of diabetic retinopathy. Diabetes Care. 2012;35:556-64.

4. Thomas MK, Demay MB. Vitamin D deficiency and disorders of vitamin D metabolism. Endocrinol Metab Clin North Am. 2000;29:611-27.

5. Muscogiuri G, Sorice GP, Ajjan R, Mezza T, Pilz S, Prioletta A, et al. Can vitamin $\mathrm{D}$ deficiency cause diabetes and cardiovascular diseases? Present evidence and future perspectives. Nutr Metab Cardiovasc Dis. 2012;22:81-7.

6. Chakhtoura M, Azar ST. The role of vitamin d deficiency in the incidence, progression, and complications of type 1 diabetes mellitus. Int $\mathrm{J}$ Endocrinol. 2013;2013:148673.

7. Riachy R, Vandewalle B, Belaich S, Kerr-Conte J, Gmyr V, Zerimech F, et al. Beneficial effect of 1,25 dihydroxyvitamin D3 on cytokine-treated human pancreatic islets. J Endocrinol. 2001;169:161-8.

8. Mathieu C. Vitamin D and diabetes: where do we stand? Diabetes Res Clin Pract. 2015;108:201-9.

9. Penna-Martinez M, Badenhoop K. Inherited variation in Vitamin d genes and type 1 diabetes predisposition. Genes. 2017;8:2-9.

10. Ben-Shoshan M, Amir S, Dang DT, Dang LH, Weisman Y, Mabjeesh NJ. 1alpha,25-dihydroxyvitamin D3 (Calcitriol) inhibits hypoxia-inducible factor-1/vascular endothelial growth factor pathway in human cancer cells.. Mol Cancer Ther. 2007;6:1433-9.

11. Lu L, Lu Q, Chen W, Li J, Li C, Zheng Z. Vitamin D 3 protects against diabetic retinopathy by inhibiting high-glucose-induced activation of the ROS/TXNIP/NLRP3 inflammasome pathway. J Diabetes Res. 2018;2018:1-11.

12. Ren Z, Li W, Zhao Q, Ma L, Zhu J. The impact of 1,25-dihydroxy vitamin D3 on the expressions of vascular endothelial growth factor and transforming growth factor- $\beta 1$ in the retinas of rats with diabetes. Diabetes Res Clin Pract. 2012;98:474-80.

13. Taverna MJ, Selam JL, Slama G. Association between a protein polymorphism in the start codon of the vitamin $D$ receptor gene and severe diabetic retinopathy in C-peptide-negative type 1 diabetes. J Clin Endocrinol Metab. 2005;90:4803-8.

14. Alcubierre N, Valls J, Rubinat E, Cao G, Esquerda A, Traveset A, et al. Vitamin $D$ deficiency is associated with the presence and severity of diabetic retinopathy in type 2 diabetes mellitus. J Diabetes Res. $2015 ; 2015$.

15. Luo BA, Gao F, Qin LL. The association between vitamin D deficiency and diabetic retinopathy in type 2 diabetes: a meta-analysis of observational studies. Nutrients. 2017;9:307.

16. Dow C, Mancini F, Rajaobelina K, Boutron-Ruault MC, Balkau B, Bonnet $F$, et al. Diet and risk of diabetic retinopathy: a systematic review. Eur J Epidemiol. 2018;33:141-56.

17. Zhang J, Upala S, Sanguankeo A. Relationship between vitamin D deficiency and diabetic retinopathy: a meta-analysis. Can J Ophthalmol I J Can d'Ophtalmologie. 2017;52:219-24.

18. Kaur H, Donaghue KC, Chan AK, Benitez-Aguirre P, Hing S, Lloyd M, et al. Vitamin $D$ deficiency is associated with retinopathy in children and adolescents with type 1 diabetes. Diabetes Care. 2011;34:1400-2.

19. Shimo N, Yasuda T, Kaneto H, Katakami N, Kuroda A, Sakamoto F, et al. Vitamin $D$ deficiency is significantly associated with retinopathy in young Japanese type 1 diabetic patients. Diabetes Res Clin Pract. 2014;106:e41-3.

20. Joergensen $C$, Hovind P, Schmedes A, Parving HH, Rossing P. Vitamin $D$ levels, microvascular complications, and mortality in type 1 diabetes. Diabetes Care. 2011;34:1081-5.

21. Engelen L, Schalkwijk CG, Eussen SJ, Scheijen JL, SoedamahMuthu SS, Chaturvedi $\mathrm{N}$, et al. Low 25-hydroxyvitamin D2 and 25-hydroxyvitamin D3 levels are independently associated with macroalbuminuria, but not with retinopathy and macrovascular disease in type 1 diabetes: the EURODIAB prospective complications study. Cardiovasc Diabetol. 2015;14:67.

22. Instituto Nacional de Estatística. Census 2011. [accessed 2018 Aug 20]. Available from: https://censos.ine.pt/xportal/ xmain? $x$ pid=CENSOS\&xpgid=ine_censos_publicacao_ det\&contexto=pu\&PUBLICACOESpub_boui=156638623\&PUBLICACO $E S m o d o=2 \&$ selTab=tab1\&pcensos $=61969554$.

23. Jorge Z, Lacerda Nobre E, Macedo A, Jácome de Castro J. Prevalência da diabetes mellitus tipo 1 em Portugal, 1995-1999: coorte de jovens do sexo masculino. Acta Med Port. 2003;16:251-3.

24. Wilkinson CP, Ferris FL $3^{\text {rd }}$, Klein RE, Lee PP, Agardh CD, Davis M, et al. Proposed international clinical diabetic retinopathy and diabetic macular edema disease severity scales. Ophthalmology. 2003;110:1677-82.

25. Holick MF, Binkley NC, Bischoff-Ferrari HA, Gordon CM, Hanley DA, Heaney RP, et al. Evaluation, treatment, and prevention of vitamin $\mathrm{D}$ deficiency: an endocrine society clinical practice guideline. J Clin Endocrinol Metab. 2011;96:1911-30.

26. Levey AS, Stevens LA, Schmid CH, Zhang Y, Castro AF, Feldman HI, et al. A new equation to estimate glomerular filtration rate. Ann Intern Med. 2009;150:604-12.

27. American Diabetes Association. 6. Glycemic targets: Standards of medical care in diabetes-2019. Diabetes Care. 2019;42:S61-70.

28. Rashidbeygi E, Rahimi MH, Mollahosseini M, Yekaninejad MS, Imani $\mathrm{H}$, Maghbooli $\mathrm{Z}$, et al. Associations of vitamin D status and metabolic dyslipidemia and hypertriglyceridemic waist phenotype in apparently healthy adults. Diabetes Metab Syndr Clin Res Rev. 2018;12:985-90.

29. Chen S, Sun Y, Agrawal DK. Vitamin D deficiency and essential hypertension. J Am Soc Hypertens. 2015;9:885-901.

30. Jean G, Souberbielle JC, Chazot C. Vitamin D in chronic kidney disease and dialysis patients. Nutrients. 2017;9:1-15.

31. Issa CM. Vitamin D and type 2 diabetes mellitus. Adv Exp Med Biol. 2017;996:193-205.

32. Campbell IT, Jarrett RJ, Keen H. Diurnal and seasonal variation in oral glucose tolerance: studies in the Antarctic. Diabetologia. 1975;11:13945.

33. Maestro B, Campion J, Davila N, Calle C. Stimulation expression in $\mathrm{U}-937$ by and human insulin responsiveness cells promonocytic D3 of insulin for glucose receptor transport. Endocr J. 2000;47:383-91.

34. Norman AW, Frankel JB, Heldt AM, Grodsky GM. Deficiency inhibits pancreatic secretion of insulin. Science. 1980;209:823-5.

35. Cohen-Lahav M, Douvdevani A, Chaimovitz C, Shany S. The antiinflammatory activity of 1,25-dihydroxyvitamin D3 in macrophages. J Steroid Biochem Mol Biol. 2007;103:558-62.

36. Gysemans CA, Cardozo AK, Callewaert H, Giulietti A, Hulshagen L, Bouillon $\mathrm{R}$, et al. 1,25-dihydroxyvitamin D3 modulates expression of chemokines and cytokines in pancreatic islets: implications for prevention of diabetes in nonobese diabetic mice. Endocrinology. 2005;146:1956-64.

37. Bettencourt A, Marinho A, Martins A, Silva D, Martins Da Silva B, Pinho E, et al. Vitamina D e autoimunidade na população portuguesa. Inst Nac Saúde Doutor Ricardo Jorge. 2018:9-11.

38. Raposo L, Martins S, Ferreira D, Guimarães JT, Santos AC. Vitamin D, parathyroid hormone and metabolic syndrome - the PORMETS study. BMC Endocr Disord. 2017;17:71.

39. Santos MJ, Fernandes V, Garcia FM. Carência de vitamina D numa população hospitalar: uma fotografia pela perspetiva laboratorial. Acta Med Port. 2015;28:726-34.

40. Santos A, Amaral TF, Guerra RS, Sousa AS, Álvares L, Moreira P, et al. Vitamin $D$ status and associated factors among Portuguese older adults: results from the Nutrition UP 65 cross-sectional study. BMJ Open. 2017;7:e016123.

41. Holick MF. Vitamin D deficiency. N Engl J Med. 2007;357:266-81. 